The closing session of the first International World Wide Web Conference

La session de cloture de la Première conférence internationale sur le système World-Wide Web

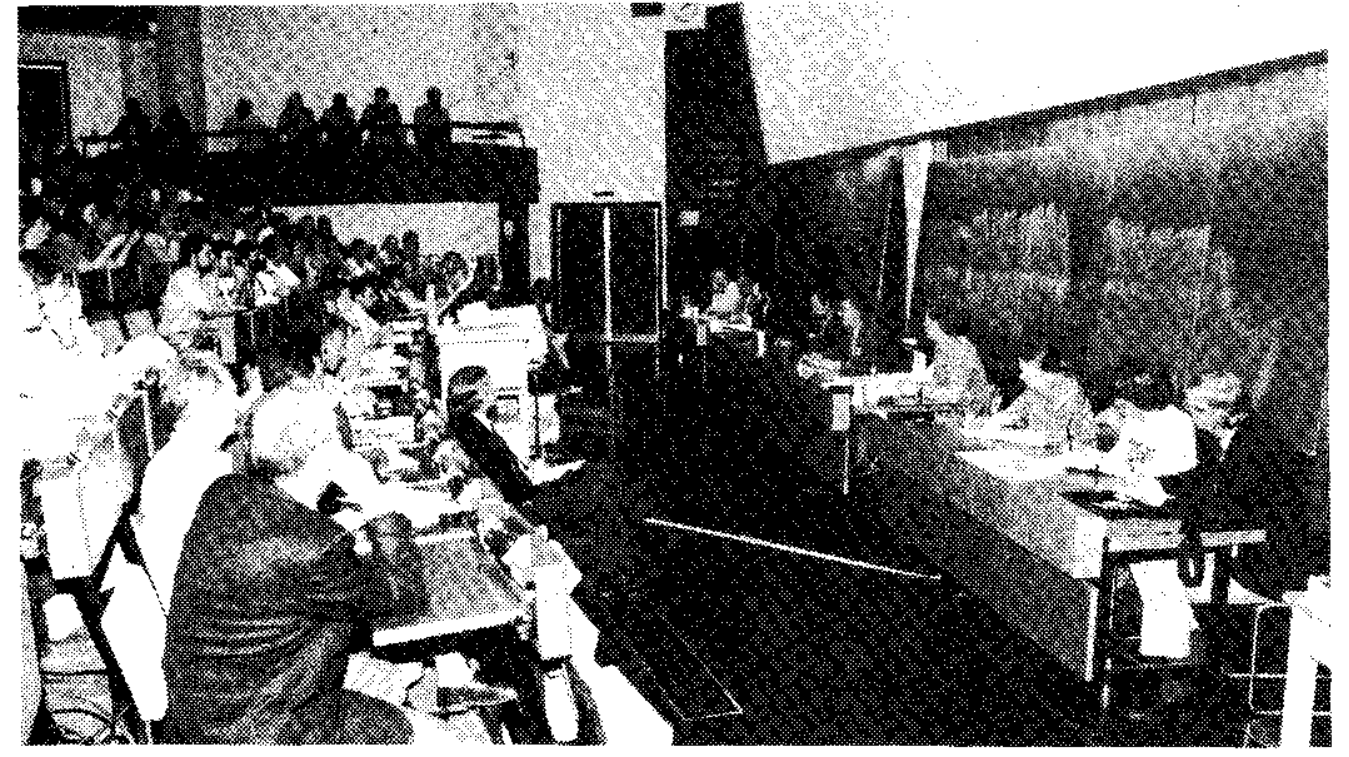

Première conférence internationale sur le système World-Wide Web

\section{First International Conference on the World-Wide Web}

World-Wide Web is the world's most powerful networked information system. It was originally conceived and developed at CERN, where large high-energy physics collaborations created a demand for instantaneous information sharing between physicists working in different universities and institutes all over the world. Now it has millions of academic and commercial users. The "Web" as it is affectionately called, runs on top of the Internet, the world's biggest interlinked set of computer networks. By installing a software package on your desktop computer, and having a network connection to the Internet, you can access all the information resources published worldwide at the click of a mouse button. Over 2 million computer systems with more than 15 million users already have access to the Internet. The Web is the delivery service on this net of Information Superhighways. Once "webbed", you find yourself in the biggest reference library in the world: full colour pictures of dinosaurs can be called up within seconds from an exhibition in Honolulu, you can walk through parts of the Vatican Library, find out what's on in the movie theatres in Iowa city, order books, or register for conferences. Practically all research and education centres have their information displayed on the Web. Many large and small businesses are starting to use the system, even in-house, as the ultimate interactive bulletin board and meeting place. The explosion of interest in World-Wide Web, which is the fastest growing service on the Internet, made it essential to hold a conference to review the current state and the future development of its services. At CERN on 25,26 and 27 May, the first World-Wide Web conference brought together people from all over the world to discuss current Web technology and to determine its future. Almost 400 networking specialists, programmers, librarians, editors, educators, scientists, government delegates and businessmen exchanged views on subjects such as security, planning for expansion and information traffic management. The results and recommendations of this conference will point the way to the future of one of the most exciting current technologies - the availability of world-wide high speed information sharing for all.
World-Wide Web est le système d'information sur réseau le plus puissant du monde. Il a été conçu et mis au point à l'origine au CERN, où de grandes collaborations en physique des hautes énergies avaient créé une demande de partage instantané de l'information entre des physiciens travaillant dans différents instituts et universités du monde entier. Ce système compte maintenant des millions d'utilisateurs du monde universitaire et du commerce. Le "Web" comme on l'appelle affectueuscment, fonctionne sur Internet, le plus grand ensemble mondial de réseaux informatiques interconnectés. En installant un progiciel sur votre ordinateur de bureau, et en étant relié par réseau à Internet, vous pouvez, simplement en cliquant sur le bouton de votre souris, accéder à toutes les sources d'informations publiées dans le monde entier. Plus de 2 millions de systèmes informatiques comptant plus de 15 millions d'utilisateurs ont déjà accès à Internet. Le Web est le service de livraison de ce réseau de superautoroutes informatiques. Une fois pris dans Web, vous vous trouvez dans la plus grande bibliothèque de références du monde: vous pouvez, en quelques secondes, appeler à l'écran des images entièrement en couleurs, de dinosaures provenant d'une exposition à Honolulu, vous promener dans des parties de la Bibliothèque vaticane, vous renseigner sur les programmes des cinémas de la ville d'lowa, commander des livres, ou vous inscrire à des conférences. Presque tous les centres de recherche et d'enseignement font paraître leurs informations sur le Web. Beaucoup de grandes et petites entreprises commencentà utiliser lesystème, mêmede manière interne, commetableau d'affichageet lieu de réunion interactifs à l'échelon le plus élevé. L'explosion d'intérêt pour WorldWide Web, le service qui se développe le plus rapidement sur Internet, a rendu indispensable la tenue d'une conférence pour examiner l'état actuel et le développement futur de ses services. Au CERN, les 25,26 et 27 mai, la première conférence sur World-Wide Web a rassemblé des participants du monde entier pour discuter del' actuelle technologiede Web et décider de son avenir. Près de 400 spécialistes des réseaux, programmeurs, bibliothécaires, rédacteurs, éducateurs, scientifiques, hauts fonctionnaires nationaux et hommes d'affaires ont échangé leurs vues sur des sujets tels que la sécurité, la planification de l'expansion et la gestion de la circulation des informations. Les résultats et recommandations decette conférence montreront où se situel'avenir del'unedes technologies actuelles les plus passionnantes-cellequi permet à tous un accès rapide à des informations du monde entier. 


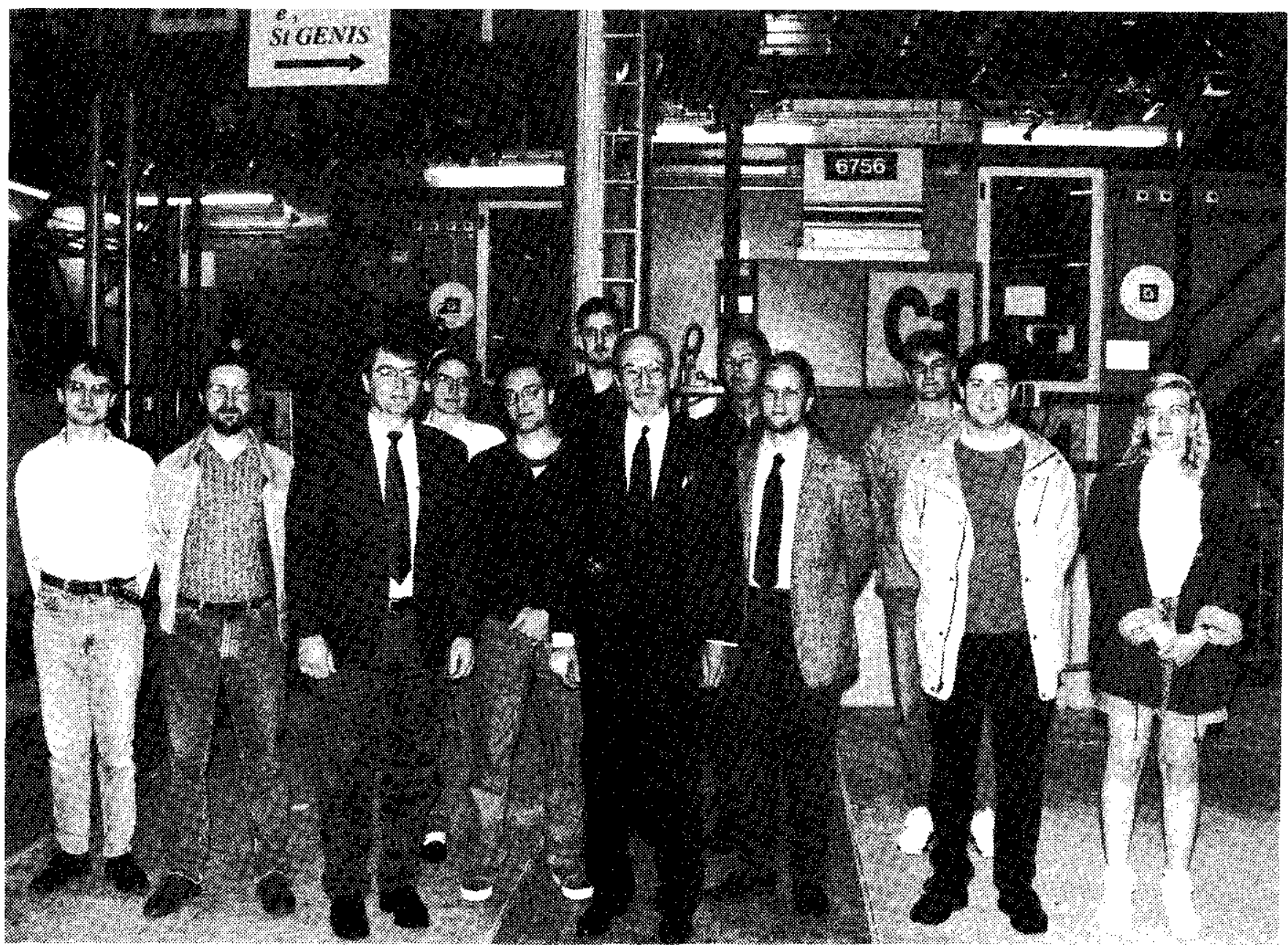

H.E. Mr M. Larry Lawrence, (centre) Ambassador of the United States of America in Berne visiting the ALEPH detector on 26 May with physicists from the Wisconsin group.
S.E. M.M. Larry Lawrence (au centre), ambassadeur des EtatsUnis d'A mérique à Berne, faisant le tour du détecteur ALEPH, le 26 mai, avec des physiciens du groupe Wisconsin.

\section{COMMUNICATIONS OFFICIELLES}

Les membres du personnel sont censés avoir pris connaissance des communications officiclles ci-après.

La reproduction même partielle de ces informations par des personnes ou des institutions externes à l'Organisation exige l'approbation préalable de la Direction du CERN.

\section{VOLS DE BIENS}

Un membre du personnel du CERN a été pris en flagrant délit de vol de matériel appartenant à l'Organisation. Il a été mis en congé spécial avec interdiction d'accès au domaine. Par ailleurs, le CERN a déposé plainte auprès de la Gendarmerie française.

Groupe de Protection des Biens Tél. 5152

\section{OFFICIAL NEWS}

Members of the personnel shall be deemed to have taken note of the news under this heading.

Reproduction of all or part of this information by persons or institutions external to the Organization requires the prior approval of the CERN management.

\section{THEFTS OF PROPERTY}

A member of the CERN personnel was recently caught in the act of stealing equipment belonging to the Organization. He was put on special leave and barred from entering CERN premises. CERN also instituted proceedings through the French police.

Property Protection Group Tel. 5152 